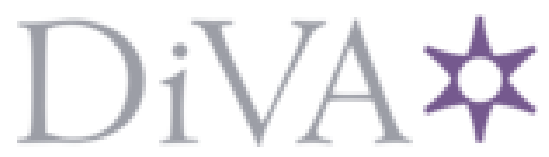

http://www.diva-portal.org

This is the published version of a paper published in Global Change Biology.

Citation for the original published paper (version of record):

Wilson, S., Nilsson, C. (2009)

Arctic alpine vegetation change over 20 years.

Global Change Biology, 15(7): 1676-1684

http://dx.doi.org/10.1111/j.1365-2486.2009.01896.x

Access to the published version may require subscription.

N.B. When citing this work, cite the original published paper.

Permanent link to this version:

http://urn.kb.se/resolve?urn=urn:nbn:se:umu:diva-23227 


\title{
Arctic alpine vegetation change over 20 years
}

\author{
SCOTT D. WILSON* and CHRISTER NILSSON† \\ *Department of Biology, University of Regina, Regina, Canada SK S4S 0A2, †Landscape Ecology Group, Department of Ecology and \\ Environmental Science, Umeå University, SE-901 87 Umeå, Sweden
}

\begin{abstract}
Recent arctic warming experiments have recorded significant vegetation responses, typically an increase in shrub cover and a loss of species richness. We report similar changes in vegetation along an arctic mountainside in northern Sweden over 20 years. During this time mean annual temperature increased by $2.0^{\circ} \mathrm{C}$, and growing season temperature by $2.3{ }^{\circ} \mathrm{C}$. Growing season length increased by $28 \%$ at the bottom of our study area, in birch forest, and by $175 \%$ on the mountaintop. Neither total vegetation cover nor the cover of bare ground changed. One common dwarf shrub, Empetrum hermaphroditum, and two common forbs, Viola biflora and Geranium sylvaticum, increased in abundance over time, but no common species moved up the gradient. Species richness declined significantly over time, with an average loss of two species per $50 \mathrm{~cm} \times 100 \mathrm{~cm}$ plot. The richness of herbaceous species at intermediate altitudes decreased significantly with increasing shrub cover. In spite of large changes in temperature, the type and magnitude of vegetation change along this mountainside were relatively modest and consistent with those from wide-spread warming experiments.
\end{abstract}

Keywords: climate change, competition, diversity, gradient, growing season length, growth form, homeostasis, shrub, warming experiments

Received 10 October 2008; revised version received 21 January 2009 and accepted 3 February 2009

\section{Introduction}

The effects of global climate change on vegetation may be especially pronounced in arctic and alpine regions which are warming faster than other areas, causing relatively large increases in the length of the growing season (Parmesan \& Yohe, 2003; Root et al., 2003). Evidence for warming-related vegetation change in these systems is of two types: arctic warming experiments and large-scale alpine surveys. Here we present results from an arctic alpine survey that confirm trends observed in warming experiments.

Arctic warming experiments typically produce statistically significant but modest vegetation responses (Chapin et al., 1995; Harte \& Shaw, 1995; Hobbie \& Chapin, 1998; De Valpine \& Harte, 2001; Jónsdóttir et al., 2005), even in global meta-analyses involving many experiments (Arft et al., 1999; Cornelissen et al., 2001; Dormann \& Woodin, 2002; Van Wijk et al., 2004; Walker et al., 2006). Modest responses are not very surprising given the capacity of ecosystems to buffer change, via mechanisms such as slow responses of biogeochemical

Correspondence: Scott D. Wilson, tel. + 306585 4201, fax + 306 337 2410, e-mail: scott.wilson@uregina.ca pools (De Valpine \& Harte, 2001; Euskirchen et al., 2006), negative feedbacks (Camill \& Clark, 2001; Dormann \& Woodin, 2002), the dominance of long-lived perennial species (Nilsson \& Wilson, 1991; Jonasson \& Shaver, 1999), the presence of other important drivers such as grazing (Grime et al., 2008; Moen \& Lagerström, 2008), and especially the normal spatial and temporal variability present regardless of global change (Epstein et al., 2004). A consistent response from arctic warming experiments is a significant increase in shrub cover and a loss of species richness (Chapin et al., 2005; Walker et al., 2006).

In contrast, large-scale alpine surveys tend to find evidence for dramatic upward movement of plant species, on the order of 1-4 $\mathrm{m} \mathrm{yr}^{-1}$ (Kullman, 2002; Klanderud \& Birks, 2003; Walther et al., 2005; Payette, 2007; le Roux \& McGeoch, 2008; Lenoir et al., 2008), a figure confirmed by paleoecological data (Tinner \& Kaltenreider, 2005). Models suggest that these figures may be underestimates (Trivedi et al., 2008). Vegetation might move upwards along mountainsides, resulting in species being 'squeezed off' the tops of mountains (Grabherr et al., 1994; Guisan \& Theurillat, 2000; Theurillat \& Guisan, 2001; Raxworthy et al., 2008) and the edges of continents (Virkkala et al., 2008). To some extent, these strong effects may have resulted from intense searches: 
large changes are reported when mountainsides are searched exhaustively (as opposed to sampled) (Kullman, 2002; Walther et al., 2005; Cannone et al., 2007) and when large numbers of samples are considered (Lenoir et al., 2008). Other strong signals of biotic responses to warming also rely on very large sample sizes (Rosenzweig et al., 2008).

The contrast between these approaches raises questions about the realism of short term, small-scale arctic warming experiments. Here we bridge the gap between arctic warming and alpine gradient studies by testing for changes in alpine zonation in an arctic area with rates of warming that are comparable to those used in experiments (Cornelissen et al., 2001; Van Wijk et al., 2004). We compared the distributions of major growth forms, common species, and species richness from the treeline to a peak in 1987 and 2007. Changes in growing season temperature and in the length of the growing season were also examined.

\section{Methods}

We sampled mountainside vegetation on Cievrratjåkka $\left(67^{\circ} 61^{\prime} \mathrm{N}, 18^{\circ} 49^{\prime} \mathrm{E}\right)$, a mountain in northern Sweden in late July of 1987 (Nilsson \& Wilson, 1991) and 2007. The vegetation is underlain by morainic deposits (Melander, 1975). The mean annual temperature at the nearest meteorological station with long-term data (Nikkaluokta, $10 \mathrm{~km} \mathrm{E}, 467 \mathrm{~m}$ a.s.l.) is $-2.0^{\circ} \mathrm{C}$, with mean January and July temperatures of -14.3 and $13.1^{\circ} \mathrm{C}$, respectively. The growing season, when the mean temperature at ground level is $>3{ }^{\circ} \mathrm{C}$ (Lundqvist, 1971), is $<130$ days; mean annual precipitation is $511 \mathrm{~mm}$. Annual precipitation increases rapidly westward and is approximately $900-1000 \mathrm{~mm}$ at the study site (Ångström, 1974). Mean duration of snow cover is 210 days (Ångström, 1974). The vegetation is free from anthropogenic disturbance apart from reindeer grazing which appeared to be minimal in both sample years based on an absence of scat, trampling, and chewed vegetation. There was no evidence of land-use change that can affect alpine vegetation (Britton \& Fisher, 2007).

We considered the range of elevation along a line running from the western summit of Cievvratjakka (1280 $\mathrm{m}$ a.s.l.) south to the treeline $(780 \mathrm{~m})$, at 10 levels separated by $50 \mathrm{~m}$ in altitude.

\section{Climate}

We determined mean annual temperature and growing season temperature (May-September) based on monthly data from Tarfala ( $1150 \mathrm{~m}$ a.s.l., $7 \mathrm{~km} \mathrm{~W}$ of the study site) for the period 1987-2007.
We examined changes in the length of the growing season for each altitude in our study during 1987-2007 using daily temperature data from Nikkaluokta, the closest station with daily data for most of this period. Data were unavailable for 1988-1990, 1995, and 2001. We assumed an adiabatic cooling rate of $1{ }^{\circ} \mathrm{C} / 100 \mathrm{~m}$ altitude (Liljequist, 1970), and calculated the number of days with a mean temperature $>3{ }^{\circ} \mathrm{C}$ (Lundqvist, 1971) annually for each altitude level. Similar temperaturebased definitions of growing season (Molau, 1996; Körner \& Paulsen, 2004) and lapse rates (Barry, 1992) could also be used, but would not alter the overall outcome.

\section{Vegetation}

At each altitude, a 100-m long transect ran perpendicular to the slope. Ten quadrats $(50 \mathrm{~cm} \times 100 \mathrm{~cm})$ were randomly arrayed along each transect. It was not possible to mark permanently the quadrats on the shifting stony ground during the first sample, and the quadrats were positioned randomly each year. The cover of each species, as well as bare ground, was assigned to one of six cover classes $(1-5 \%, 6-25 \%, 26-50 \%, 51-75 \%$, 76-95\%, 96-100\%) (Daubenmire, 1959), and the mean value recorded for each. Nomenclature follows http:// linnaeus.nrm.se/flora/.

We examined variation in the total covers of all vascular plant species, evergreen and deciduous woody plants, forbs, graminoids, the five most common woody and herbaceous species, and bare ground. We also examined total species richness, woody species richness, and herbaceous species richness. Smaller classes of growth forms (e.g. evergreen and deciduous woody species) were not examined for variation in richness because of the low values for some groups. Proportional data were arcsine-square root transformed before analysis, and other data were $\log _{10}$ transformed.

We used two-factor analysis of variance (ANOVA) to test whether vegetation varied significantly with year, altitude, or the interaction between these factors. We paid special attention to year effects and interactions between year and altitude. In cases where both year and the interaction were significant, pairwise comparisons within ANOVA tested for significant differences between years at each altitude. In cases without a significant main year effect, but where both altitude and the interaction between altitude and year were significant, pairwise comparisons within ANOVA tested for significant differences among altitudes for each year.

The large number of contrasts $(N=45)$ among 10 altitude levels was reduced to facilitate interpretation. This was done by pooling the 10 altitudes into five classes based on dominant vegetation: (1) birch forest (the lowest transect, $785 \mathrm{~m})$; (2) heath $(840$ and $895 \mathrm{~m}$ ); 
(3) mixed tundra (950, 1005, $1060 \mathrm{~m})$; (4) mostly bare ground (1115, 1170, $1225 \mathrm{~m})$; and (5) mountaintop (1280 m).

Altitude levels with zeroes in both years for a particular variable (e.g. woody cover at the highest level) were excluded from analysis.

\section{Results}

Climate

Mean annual temperature increased significantly during 1987-2007 $\left(R^{2}=0.58, P<0.0001\right.$, Fig. 1a), with a slope of $0.099^{\circ} \mathrm{C} \mathrm{yr}^{-1}$, for a total increase of $2.0^{\circ} \mathrm{C}$ over 20 years. Mean growing season temperature also increased $\left(R^{2}=0.50, P<0.001\right.$, Fig. 1a), with a slope of $0.116^{\circ} \mathrm{C} \mathrm{yr}^{-1}$, for a total increase of $2.3^{\circ} \mathrm{C}$ over 20 years.

Growing season length increased significantly with time (Fig. 1b). Further, higher altitude sites gained relatively more days at $>3{ }^{\circ} \mathrm{C}$ than lower altitude sites. The slope of the relationship between growing season length and year increased significantly with altitude $\left(R^{2}=0.92, P<0.001\right.$ for all 10 altitudes considered together, data not shown), from 1.25 at the lowest altitude to 1.66 at the highest (Fig. 1b).

Growing season length at the lowest altitude in-

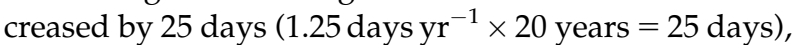
a $28 \%$ increase expressed as a proportion of the length of the growing season in 1987 (89 days). In contrast, growing season length at the highest altitude increased by 33 days $(1.66 \times 20=33$ days $)$, a $175 \%$ increase expressed as a proportion of the length of the growing season in 1987 (19 days). In summary, growing season length increased over time, especially at high altitude.

\section{Vegetation}

In general, variation with altitude was much greater than changes between years for vegetation variables. Total plant cover decreased with altitude but did not differ significantly between years (Fig. 2a). A significant interaction between altitude and year occurred because cover in birch forest was significantly greater than in heath in 2007 but not in 1987.

Woody evergreen cover varied significantly with altitude and was greatest at intermediate levels (Fig. $2 b$ ). A significant interaction between altitude and year occurred because cover varied more strongly with altitude in 2007 than 1987.

Woody deciduous cover decreased significantly with altitude but did not vary with year or its interaction (Fig. 2c).

The most abundant woody species, the evergreen shrub Empetrum hermaphroditum, varied significantly
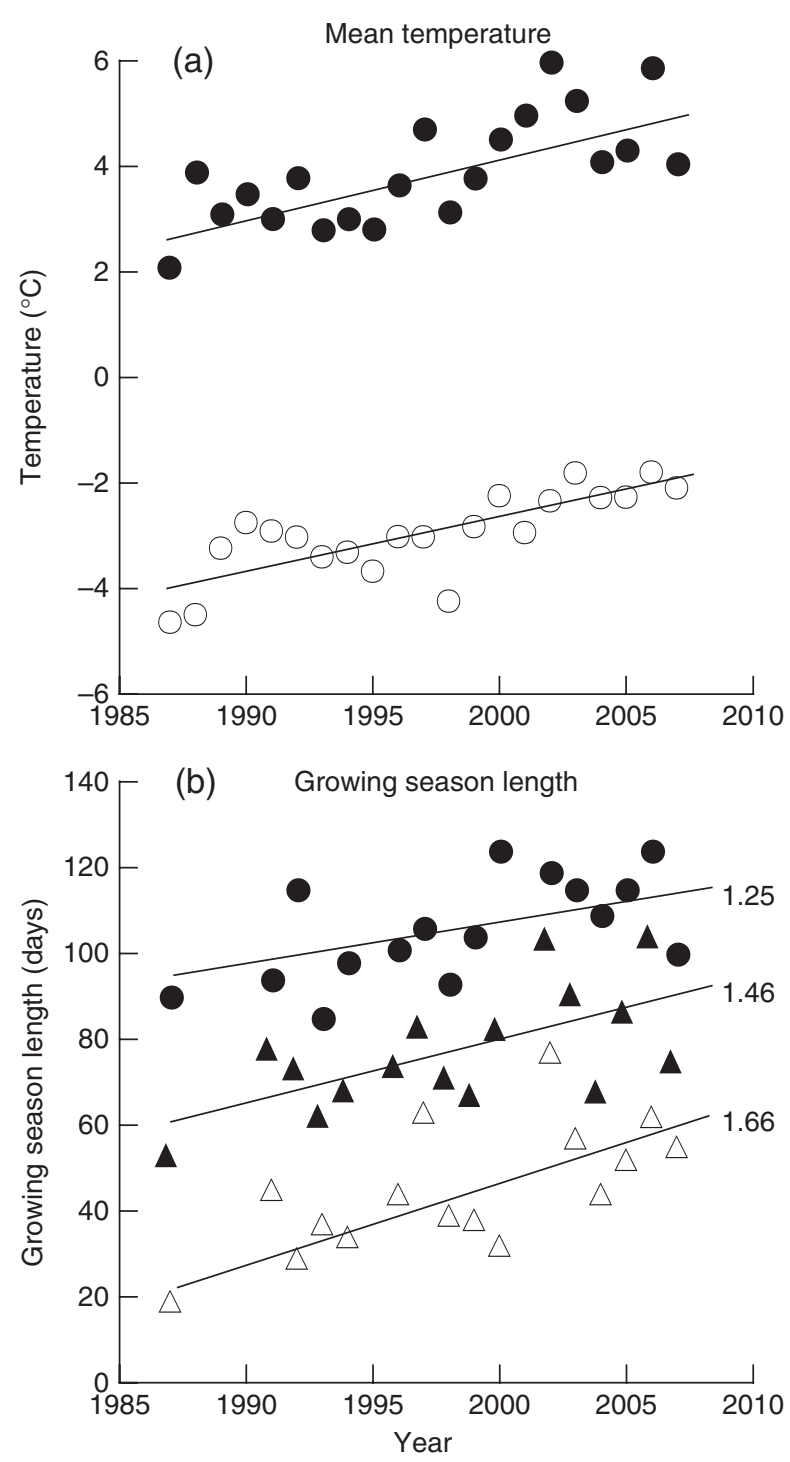

Fig. 1 (a) Mean temperature for the growing season (MaySeptember, solid circles) and for the entire year (open circles) during 1987-2007, at Tarfala ( $1150 \mathrm{~m}$ a.s.l., $7 \mathrm{~km}$ from the study site). (b) Growing season length (number of days with mean temperature $>3^{\circ} \mathrm{C}$ ) as a function of year, at the lowest altitude (circles, $780 \mathrm{~m}$ a.s.l.), at an intermediate altitude (solid triangles, 1005 ma.s.1.), and at the highest altitude (open triangles, $1280 \mathrm{~m}$ a.s.l.). Values were calculated using data from Nikkaluokta $(10 \mathrm{~km}$ from the study site) and standard lapse rates. Numbers: slope of the regression line for each altitude (all $P<0.05$ ), equivalent to the increase in the length of the growing season (in days) each year. Only three altitudes are shown for clarity.

with both altitude and year, and their interaction (Fig. $3 d$ ). The interaction occurred because cover increased over time only in heath (Fig. 3d). The deciduous shrub Vaccinium myrtillus also varied with both factors and their interaction; the interaction reflected a significant 
decrease in forest (Fig. 3a). The other three most common woody species varied significantly with altitude but not with year or the interaction (Fig. 3). These had greatest cover at intermediate altitudes.
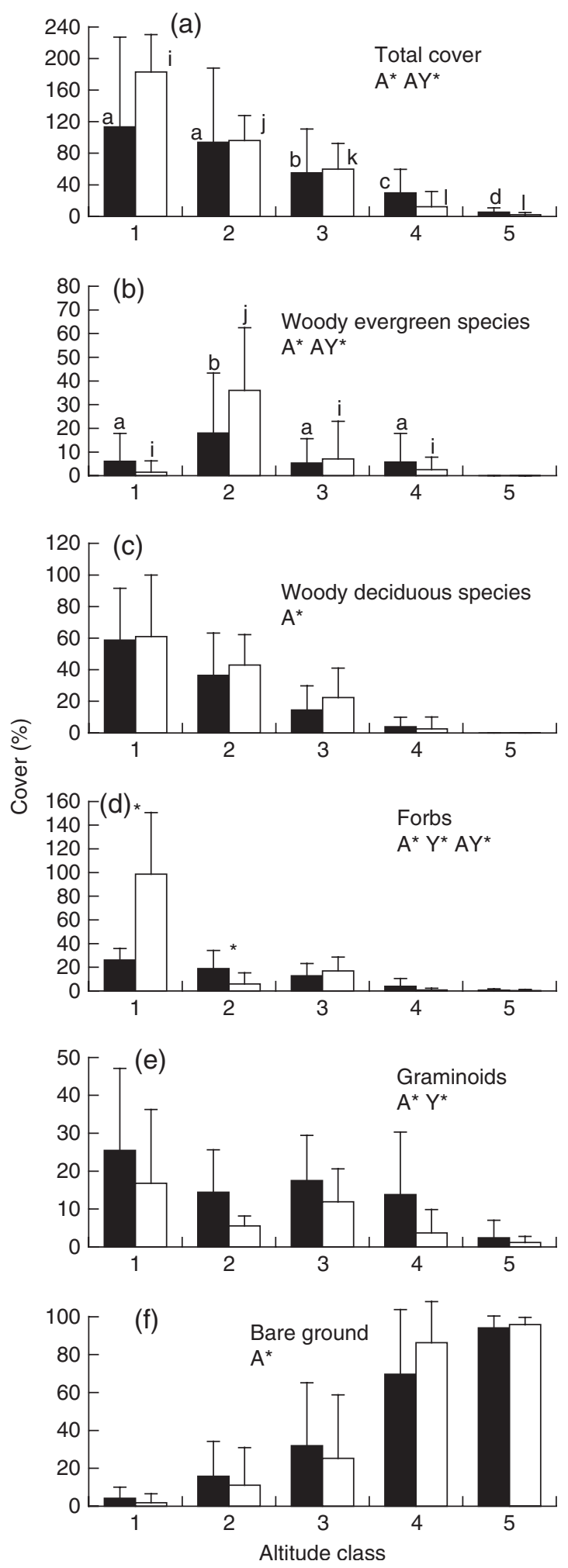

Forb cover decreased with altitude and varied significantly between years (Fig. 2d). An interaction between altitude and year reflected an increase in forb cover in forest and a decrease in heath.

Graminoid cover decreased significantly with both altitude and year (Fig. 2e). The lack of an interaction between factors suggests that the decrease between years did not vary with altitude.

Three of the five most abundant herbaceous species differed between years. The forbs Viola biflora and Geranium sylvaticum increased greatly in forest plots (Fig. 4a and b). In contrast, the grass Deschampsia flexuosa disappeared from forest plots but persisted at higher altitudes (Fig. 4c). The grass Festuca ovina and the forb Solidago virgaurea did not vary with year or its interaction with altitude (Fig. $4 \mathrm{~d}$ and e).

Bare ground increased with altitude but did not vary between years (Fig. 2f).

Total species richness declined significantly with altitude and time, and was on average two species lower per study plot in 2007 (Fig. 5a). The lack of an interaction between factors suggested that the decrease over time did not vary with altitude.

Woody species richness did not differ with the main effect of year but varied significantly with altitude and the interaction between year and altitude (Fig. 5b). In 1987 richness decreased steadily with altitude, but in 2007 richness varied less among the three lowest altitude classes.

Herbaceous species richness (Fig. 5c) showed the same response as total richness. In heath, herbaceous species richness decreased significantly with increasing cover of woody species (Fig. $6 ; F_{1,39}=11.48, P<0.01$ ). Maximum values for herbaceous richness occurred in 1987, whereas values for woody cover tended to be greatest in 2007.

\section{Discussion}

Relatively large increases in temperature were accompanied by considerable variation among growth forms and species in their individual responses. Divergent

Fig. 2 Total cover (mean $+\mathrm{SE}$ ) of all vegetation, woody evergreen species, woody deciduous species, forbs, graminoids and bare ground in 1987 (solid bars) and 2007 (open bars) in five altitude classes: (1) birch forest; (2) heath; (3) mixed tundra; (4) bare ground; (5) mountaintop. A, altitude effect; $Y$, year effect; $\mathrm{AY}$, interaction; ${ }^{*} P<0.05$. Lower-case letters denote pairwise contrasts among altitude levels for each year for cases in which both altitude and the year $\times$ altitude interactions were significant. *Indicates significant differences between years at a particular altitude in cases in which both year and the year $\times$ altitude interactions were significant. 

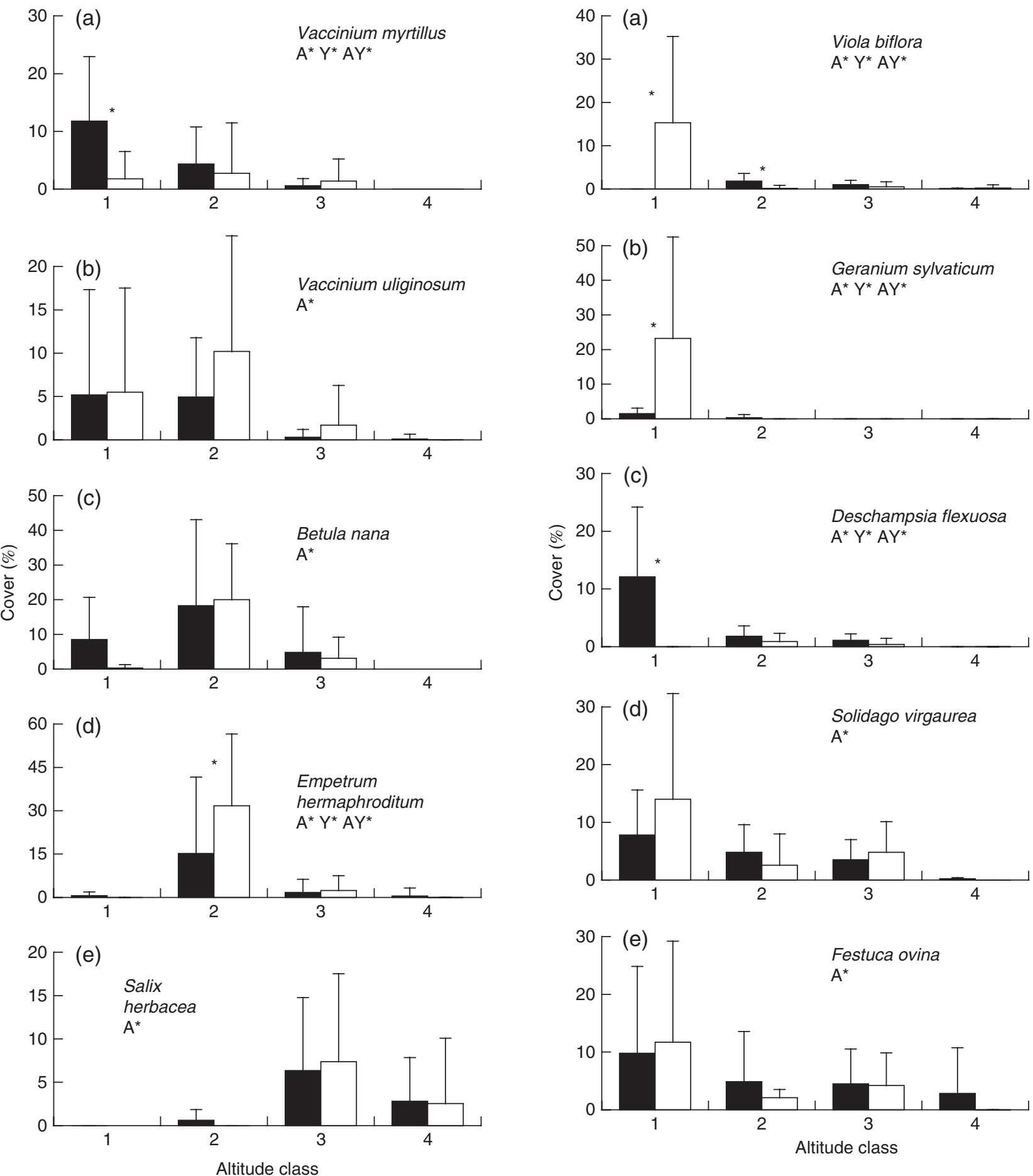

Fig. 3 Covers (mean $+\mathrm{SD}$ ) of the five most abundant woody species in 1987 (solid bars) and 2007 (open bars) in four altitude classes: (1) birch forest; (2) heath; (3) mixed tundra; (4) bare ground. A, altitude effect; $Y$, year effect; AY, interaction; ${ }^{*} P<0.05$. *Indicates significant differences between years at a particular altitude in cases in which both year and the year $\times$ altitude interactions were significant.

Fig. 4 Covers (mean $+\mathrm{SD}$ ) of the five most abundant herbaceous species in 1987 (solid bars) and 2007 (open bars) in four altitude classes: (1) birch forest; (2) heath; (3) mixed tundra; (4) bare ground. A: altitude effect; $Y$, year effect; AY, interaction; ${ }^{*} P<0.05$. ${ }^{*}$ Indicates significant differences between years at a particular altitude in cases in which both year and the year $\times$ altitude interactions were significant. 

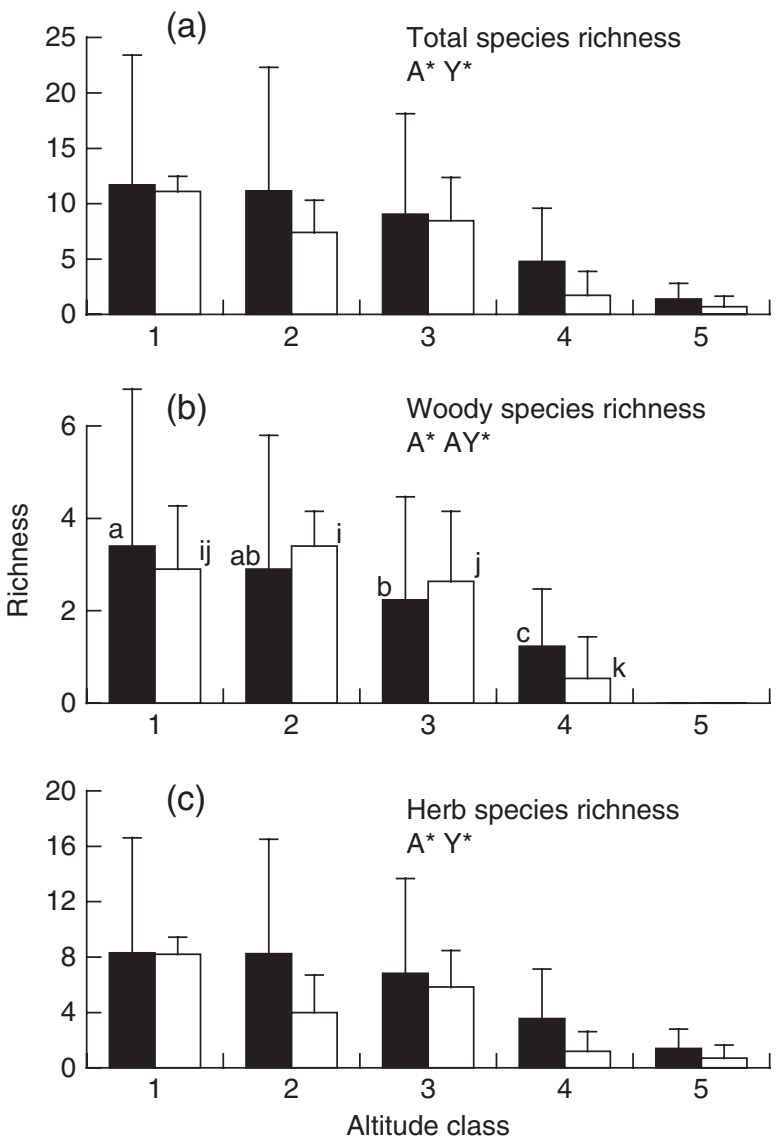

Fig. 5 Species richness (Mean $+\mathrm{SD}$ ), per $50 \mathrm{~cm} \times 100 \mathrm{~cm}$ plot, of (a) all, (b) woody, and (c) herbaceous species in 1987 (solid bars) and 2007 (open bars) in five altitude classes: (1) birch forest; (2) heath; (3) mixed tundra; (4) bare ground; (5) mountaintop. A, altitude effect; $\mathrm{Y}$, year effect; $\mathrm{AY}$, interaction; ${ }^{*} P<0.05$. Lowercase letters denote pairwise contrasts among altitude levels for each year for cases in which both altitude and the year $\times$ altitude interactions were significant.

responses are illustrated by growth form covers (Fig. 2): woody evergreens increased only in heath, woody deciduous species did not change in 20 years, forbs increased only in forest, and graminoids decreased at all altitudes. Species covers (Figs 3 and 4) and richness (Fig. 5) showed similar levels of variability among groups. Although there was no consistent response among groups, the overall decrease in richness adheres to the general observation that vegetation diversity at local scales declines with increasing productivity, represented in this case by increasing temperature and growing season length (Grime, 1979; Huston, 1979).

Our results are in line with arctic warming studies which typically find statistically significant increases in shrub cover (Chapin et al., 1995; Harte \& Shaw, 1995; Hobbie \& Chapin, 1998; Jonasson et al., 1999; Dormann \& Woodin, 2002; Van Wijk et al., 2004; Jónsdóttir et al.,

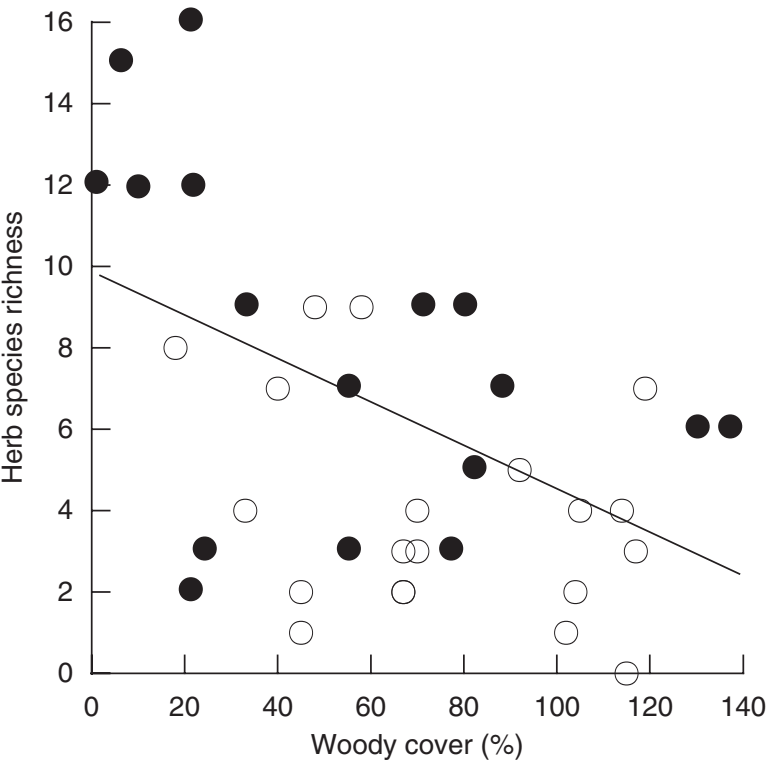

Fig. 6 Species richness of herbaceous species as a function of the total cover of woody species in 1987 (closed circles) and 2007 (open circles) in heath (altitude class 2). Regression line is for both years combined.

2005; Walker et al., 2006). There were, however, some differences: the shrubs that increase in Alaska are deciduous shrubs, especially Betula nana (Chapin et al., 1995; Arft et al., 1999). Here, B. nana did not respond, but the evergreen shrub E. hermaphroditum did (Fig. 3). Empetrum was one of the greatest increasers over 68 years on central Norwegian mountainsides (Klanderud \& Birks, 2003). At Abisko, $54 \mathrm{~km}$ from our study site, warming in one case increased all species without especially affecting shrubs (Van Wijk et al., 2004), whereas in another case both evergreen and deciduous shrubs increased (Jonasson et al., 1999). Shrub species at Abisko also had divergent responses to winter warming (Bokhorst et al., 2008). Graminoids also tend to increase in warming experiments (Walker et al., 2006), but not at our study site. There is clearly variation among species and locations (Walker et al., 2006), but overall the modest increase in shrubs and lack of other responses on our mountainside is consistent with warming experiments and long term field observations (Tape et al., 2006).

A second general experiment result from warming studies confirmed by our gradient analysis was a significant decrease in species richness (Fig. 5). Metaanalyses show that warming drives decreases in certain groups and increases in others (Cornelissen et al., 2001; De Valpine \& Harte, 2001). An increase in shrubs was associated with a loss of richness in early warming experiments (Chapin et al., 1995; Harte \& Shaw, 1995) and in later meta-analyses (Walker et al., 2006). Forb 
richness and shrub cover were also negatively related in our study (Fig. 6). In spite of this, richness showed no statistical interaction between altitude and year (Fig. $5 a)$, suggesting that species loss was similar along the entire gradient. The most likely scenario for the loss of richness is a decline in abundance of relatively rare species (Saetersdal \& Birks, 1997), resulting in their absence from the sampled vegetation.

Lastly, our results confirm a trend for larger changes in relatively moderate environments and less change in harsher environments. Significant differences among years in this study were all restricted to the lowest altitudes. Of the 10 most common species, three varied significantly at the lowest altitude class (Fig. $4 a-c$ ), one at the second-lowest (Fig. 3d), and none above. Our vegetation results are consistent with an Italian mountainside, where shrubs increased over 50 years, but higher-altitude vegetation decreased in cover (Cannone et al., 2007). Alpine vegetation changes during 68 years in central Norway were greatest at lowest altitudes (Klanderud \& Birks, 2003). Similarly, spruce trees ascended mountainsides in coastal Labrador, but receded at inland stations (Payette, 2007). Experimental warming increased shrub cover in an Icelandic heath but had no effect on a higher elevation moss community (Jónsdóttir et al., 2005). Meta-analyses of warming experiments found the strongest growth responses in the lowest plots (Arft et al., 1999) and evidence for competitive displacement by vascular plants in lower plots but not higher (Cornelissen et al., 2001). Ecosystem models produce similar results (Euskirchen et al., 2006). The difference is likely due to greater amounts of biological capital, in the form of soil organic matter and propagules, at lower levels.

Finding the strongest biotic responses at the lowest elevation is not consistent with the location of the greatest change in climate, at the highest elevation. On the mountaintop, the length of the growing season increased so much that in 2007 the mountaintop enjoyed the same length of growing season as an altitude $275 \mathrm{~m}$ lower did 20 years earlier (Fig. 2, note the vertical overlap in open triangles in 2007 and closed triangles in 1987). Growing season length increased nearly three times at the mountaintop, but only fractionally at the lowest altitude. Similar results appear from cross-latitude models (Euskirchen et al., 2006). The disparity between climate change (greatest at the top) and vegetation change (greatest at the bottom) reinforces the concept of ecosystems having great capacity to buffer temperature changes (Camill \& Clark, 2001; De Valpine \& Harte, 2001; Theurillat \& Guisan, 2001; Dormann \& Woodin, 2002; Euskirchen et al., 2006). Our results support the idea that relatively fast growing vegetation, such as that at the bottom of our elevation gradient, may be more sensitive to climate change than slow growing vegetation, such as that at the top of the mountain (Grime et al., 2008). These results, as well as ours, do not support modeled predictions of large changes in mountaintop floras (Guisan \& Theurillat, 2000; Theurillat \& Guisan, 2001). On the other hand, our results are consistent with observations that most Nordic alpine plants have relatively broad temperature tolerances and thus might show little response to warming (Saetersdal \& Birks, 1997).

Further, climate-induced change must be compared with the normal spatial and temporal variability in conditions that is normally present (Epstein et al., 2004). A well-studied glacier $8 \mathrm{~km}$ from our site has been losing mass steadily since about 1750 (Linderholm et al., 2007), suggesting that vegetation in our region has experienced steady warming for centuries.

Our arctic-alpine vegetation should show relatively strong responses to warming because mean annual temperature increased $2.0^{\circ} \mathrm{C}$ over 20 years, much higher than the global average of $0.6^{\circ} \mathrm{C}$ over 100 years (Root et al., 2003). In this sense, the mountainside served as a natural experiment with a strong but realistic warming treatment.

In spite of very large increases in annual temperature, our study system does not confirm reports of large upslope migrations. Over our 20-year sample period, rates reported elsewhere, averaging $3 \mathrm{~m} \mathrm{yr}^{-1}$ (Kullman, 2002; Tinner \& Kaltenreider, 2005; Walther et al., 2005; Payette, 2007; le Roux \& McGeoch, 2008; Lenoir et al., 2008), could be expected to produce shifts of $60 \mathrm{~m}$ in elevation. No variable, however, shifted upward. The number of samples that detect shifts, $N=4000-28000$ (Lenoir et al., 2008; Rosenzweig et al., 2008) are outside the realm of experimental study, as is the complete censusing of large areas (Kullman, 2002; Cannone et al., 2007). Normal sample sizes, like ours $(N=200)$ do not show big shifts. Thus, while some species shifts are detectable with very intensive searching, the relative importance of climate change in experiments is small compared with other experimentally-manipulated factors such as grazing, ultraviolet radiation, water, and nutrients (Walker et al., 2006).

Another large change in our study was an increase in herbaceous vegetation in the forest. Total forb cover and the covers of the forbs V. biflora and G. sylvaticum, as well as the small deciduous shrub $V$. myrtillus, increased significantly between years. In contrast, the grass $D$. flexuosa, typical of dry or moderately mesic areas, disappeared from forest plots. Taken together, the results suggest that forest plots had more available moisture in 2007. This might have arisen due to long-term changes in drainage, or because of earlier snow melt brought on by higher temperatures. 
In summary, our mountainside study carried out at the same sampling intensity as experimental studies found similar significant changes associated with warming, especially increased shrub cover and reduced richness. Our gradient analysis confirmed that the greatest changes occur at lowest elevations, and suggest that the complex nature of ecosystems will ensure that species do not rapidly track changes in annual temperature.

\section{Acknowledgements}

We thank L. Hammarberg for field assistance, P. Jansson for Tarfala climate data, anonymous reviewers for comments, and the Natural Sciences and Engineering Research Council of Canada for support.

\section{References}

Ångström A (1974) Sveriges Klimat. Generalstaben, Stockholm. Arft AM, Walker MD, Gurevitch J et al. (1999) Responses of tundra plants to experimental warming: meta-analysis of the International Tundra Experiment Ecological Monographs, 69, 491-512.

Barry RG (1992) Mountain Weather and Climate. Routledge, New York.

Bokhorst S, Bjerke JW, Bowles FW, Melillo J, Callaghan TV, Phoenix GK (2008) Impacts of extreme winter warming in the sub-Arctic: growing season responses of dwarf shrub heathland. Global Change Biology, 14, 2603-2612.

Britton A, Fisher J (2007) NP stoichiometry of low-alpine heathland: usefulness for bio-monitoring and prediction of pollution impacts. Biological Conservation, 138, 100-108.

Camill P, Clark JS (2001) Long-term perspectives on lagged ecosystem responses to climate change: permafrost in boreal peatlands and the grassland/woodland boundary. Ecosystems, 3, 534-544.

Cannone N, Sgorbati S, Guglielmen M (2007) Unexpected impacts of climate change on alpine vegetation. Frontiers in Ecology and the Environment, 5, 360-364.

Chapin FS III, Shaver GR, Giblin AE, Nadelhoffer KJ, Laundre JA (1995) Responses of arctic tundra to experimental and observed changes in climate. Ecology, 76, 694-711.

Chapin FS III, Sturm M, Serreze MC et al. (2005) Role of landsurface changes in arctic summer warming. Science, 310, 657-660.

Cornelissen JHC, Callaghan TV, Alatalo JM et al. (2001) Global change and arctic ecosystems: is lichen decline a function of increases in vascular plant biomass? Journal of Ecology, 89, 984-994.

Daubenmire R (1959) Canopy-coverage method of vegetational analysis. Northwest Science, 33, 43-64.

De Valpine P, Harte J (2001) Plant responses to experimental warming in a montane meadow. Ecology, 82, 637-648.

Dormann CF, Woodin SJ (2002) Climate change in the Arctic: using plant functional types in a meta-analysis of field experiments. Functional Ecology, 16, 4-17.
Epstein HE, Calef MP, Walker MD, Chapin FS III, Starfield AM (2004) Detecting changes in arctic tundra plant communities in response to warming over decadal time scales. Global Change Biology, 10, 1325-1334.

Euskirchen ES, McGuire AD, Koicklighter DW et al. (2006) Importance of recent shifts in soil thermal dynamics on growing season length, productivity, and carbon sequestration in terrestrial high-latitude ecosystems. Global Change Biology, 12, 731-750.

Grabherr G, Gottfried M, Pauli H (1994) Climate effects on mountain plants. Nature, 369, 448.

Grime JP (1979) Plant Strategies and Vegetation Processes. John Wiley, Chichester.

Grime JP, Fridley JD, Askew AP, Thompson K, Hodgson JG, Bennett CR (2008) Long-term resistance to simulated climate change in an infertile grassland. Proceedings of the National Academy of Science, 105, 10028-10032.

Guisan A, Theurillat JP (2000) Assessing alpine plant vulnerability to climate change: a modeling perspective. Integrated Assessment, 1, 307-320.

Harte J, Shaw R (1995) Shifting dominance within a montane vegetation community: results of a climate-warming experiment. Science, 267, 876-880.

Hobbie SE, Chapin FS III (1998) The response of tundra plant biomass, aboveground production, nitrogen, and $\mathrm{CO}_{2}$ flux to experimental warming. Ecology, 79, 1526-1544.

Huston M (1979) A general hypothesis of species diversity. American Naturalist, 113, 81-101.

Jonasson S, Michelsen A, Schmidt IK, Nielsen EV (1999) Responses in microbes and plants to changed temperature, nutrient, and light regimes in the arctic. Ecology, 80, $1828-1843$.

Jonasson S, Shaver GR (1999) Within-stand nutrient cycling in arctic and boreal wetlands. Ecology, 80, 2139-2150.

Jónsdóttir IS, Magnússon B, Gudmundsson J, Elmarsdóttir A, Hjartarson H (2005) Variable sensitivity of plant communities in Iceland to experimental warming. Global Change Biology, 11, 553-563.

Klanderud K, Birks HJB (2003) Recent increases in species richness and shifts in altitudinal distributions of Norwegian mountain plants. The Holocene, 13, 1-6.

Körner C, Paulsen J (2004) A world-wide study of high altitude treeline temperatures. Journal of Biogeography, 31, 713-732.

Kullman L (2002) Rapid recent range-margin rise of tree and shrub species in the Swedish Scandes. Journal of Ecology, 90, 68-77.

le Roux PC, McGeoch MA (2008) Rapid range expansion and community reorganization in response to warming. Global Change Biology, 14, 2950-2962.

Lenoir J, Gégout J-C, Marquet PA, de Ruffray P, Brisse H (2008) A significant upward shift in plant species optimum elevation during the 20th century. Science, 320, 1768-1771.

Liljequist GH (1970) Klimatologi. Generalstaben, Stockholm. Linderholm HW, Jansson P, Chen D (2007) A high-resolution reconstruction of Storglaciären mass balance back to 1780/81 using tree-ring data and circulation indices. Quaternary Research, 67, 12-20. 
Lundqvist M (1971) Atlas över Sverige 1953-1971. Svenska Sällskapet för Antropologi och Geografi, Stockholm.

Melander O (1975) Geografiska kartbladet 29 I Kebnekaise: beskrivining och naturvärdsbedömning. National Swedish Environmental Protection Board, Solna.

Moen J, Lagerström A (2008) High species turnover and decreasing plant species richness on mountain summits in Sweden: reindeer grazing overrides climate change? Arctic, Antarctic and Alpine Research, 40, 382-395.

Molau U (1996) ITEX climate stations. In: ITEX Manual, 2nd edn (eds Molau U, Molgaard P), pp. 6-10. Danish Polar Center, Copenhagen.

Nilsson C, Wilson SD (1991) Convergence in plant community structure along disparate gradients: are lakeshores inverted mountainsides? American Naturalist, 137, 774-790.

Parmesan C, Yohe G (2003) A globally coherent fingerprint of climate change impacts across natural systems. Nature, 421, $37-42$.

Payette S (2007) Contrasted dynamics of northern Labrador tree lines caused by climate change and migrational lag. Ecology, 88, 770-780.

Raxworthy CJ, Pearson RG, Rabibisoa N et al. (2008) Extinction vulnerability of tropical montane endemism from warming and upslope displacement: a preliminary appraisal for the highest massif in Madagascar. Global Change Biology, 14, 17031720.

Root TL, Price JT, Hall KR, Schneider SH, Rosenzweig C, Pound JA (2003) Fingerprints of global warming on wild animals and plants. Nature, 421, 57-60.

Rosenzweig C, Karoly D, Vicarelli M et al. (2008) Attributing physical and biological impacts to anthropogenic climate change. Nature, 453, 353-357.
Saetersdal M, Birks HJB (1997) A comparative ecological study of Norwegian mountain plants in relation to possible future climatic change. Journal of Biogeograghy, 24, 127-152.

Tape K, Sturm W, Racine C (2006) The evidence for shrub expansion in northern Alaska and the Pan-Arctic. Global Change Biology, 12, 686-702.

Theurillat JP, Guisan A (2001) Potential impact of climate change on vegetation in the European Alps: a review. Climate Change, 50, 77-109.

Tinner W, Kaltenreider P (2005) Rapid responses of high-mountain vegetation to early Holocene environmental changes in the Swiss Alps. Journal of Ecology, 93, 938-947.

Trivedi MR, Berry PM, Morecroft MD, Dawson TP (2008) Spatial scale affects bioclimate model projections of climate change impacts on mountain plants. Global Change Biology, 14, 1089 1103.

Van Wijk MT, Clemmensen KE, Shaver GR, Williams M, Callaghan TV, Chapin FS III (2004) Long-term ecosystem level experiments in Toolik Lake, Alaska, and at Abisko, Northern Sweden: generalisations and differences in ecosystem and plant type responses to global change. Global Change Biology, 10, 105-123.

Virkkala R, Heikkinen RK, Leikola N, Luoto M (2008) Projected large-scale range reductions of northern-boreal land bird species due to climate change. Biological Conservation, 5, 1343-1353.

Walker MD, Wahren CH, Hollister RD et al. (2006) Plant community responses to experimental warming across the tundra biome. Proceedings of the National Academy of Science, 103, 1342-1346.

Walther G-R, Beißner S, Burga CA (2005) Trends in the upward shift of alpine plants. Journal of Vegetation Science, 16, 541-548. 